\title{
Effect of Cyclosporine A on the Release of Tissue Factor Pathway Inhibitor from Endothelial Cells in Heart Transplant Patients and Cell Culture
}

\author{
Carsten Tiemann ${ }^{1}$, Wolfgang Prohaska ${ }^{1}$, Reiner Körfer ${ }^{2}$, Michael Körner ${ }^{2}$, Thomas Brinkmann ${ }^{1}$ and Knut Kleesiek ${ }^{1}$ \\ ${ }^{1}$ Institut für Laboratoriums- und Transfusionsmedizin, Herz- und Diabeteszentrum Nordrhein-Westfalen, \\ Universitätsklinik der Ruhr-Universität Bochum, Bad Oeynhausen, Germany \\ ${ }^{2}$ Klinik für Thorax- und Kardiovaskularchirurgie, Herz- und Diabeteszentrum Nordrhein-Westfalen, \\ Universitätsklinik der Ruhr-Universität Bochum, Bad Oeynhausen, Germany
}

Summary: We investigated the influence of cyclosporine A on the concentration of tissue factor pathway inhibitor and von Willebrand factor antigen in plasma of heart transplant outpatients.

Tissue factor pathway inhibitor was quantified in plasma of blood donors $(n=50)$ and heart transplant outpatients $(\mathrm{n}=50)$ by a chromogenic substrate assay with a mean of $32.4 \mu \mathrm{g} / 1$ and $98.2 \mu \mathrm{g} / 1$, respectively. Von Willebrand factor antigen was determined with an enzyme-linked immunoassay with a mean of $90.9 \%$ for blood donors and $184.5 \%$ in plasma of heart transplant recipients.

In addition, we investigated the effect of cyclosporine $\mathrm{A}$ on endothelial cell cultures over an incubation period of four days. A dose-dependent effect of cyclosporine A on the release of endothelial tissue factor pathway inhibitor and von Willebrand factor antigen was determined in a concentration range from 100 to $200 \mu \mathrm{g} / 1$ cyclosporine A. The tissue factor pathway inhibitor and von Willebrand factor antigen concentrations in the cell culture supernatant increased during the incubation time according to the cyclosporine A concentration 2-3 fold and 2 fold, respectively.

For a further elucidation of the cyclosporine A effect we investigated the influence of cremophor EL, the vehicle of cyclosporine A. Cremophor EL alone did not increase the tissue factor pathway inhibitor release. However, the release was enhanced 2-4 fold after co-stimulation with the calcium ionophore A $23187\left(10^{-4} \mathrm{~mol} / \mathrm{l}\right)$ in a concentration-dependent mode.

We conclude that a generalized endothelial damage or activation is most probably caused by cyclosporine A and its vehicle cremophor EL. This process probably depends upon the increase of cytosolic free calcium, as described for the liberation of von Willebrand factor by endothelial cells.

\section{Introduction}

Cyclosporine A represents an effective immunosuppressive agent used to prevent solid organ transplant rejection and control graft-versus-host disease after allogenic bone marrow transplantation.

As described earlier, cyclosporine $\mathrm{A}$ influences the vascular endothelium, thus resulting in increased plasma concentrations of endothelial-derived proteins, as detected in plasma of immunosuppressed patients. These results were described as cytotoxic or modulatory effects on the endothelial cells $(1-3)$. The cellular surfaces may interfere with immunosuppressiva, thus increasing the expression and release of endothelial-derived proteins (4).

Based on the assumption that immunosuppressive therapy influences stimulation or damage of vascular endo- thelium, we investigated the effect of cyclosporine A on the release of tissue factor pathway inhibitor and von Willebrand factor antigen into the plasma of immunosuppressed heart transplant patients and in part in endothelial cell culture supernatants.

Tissue factor pathway inhibitor is a multivalent Kunitztype plasma protease inhibitor and is mainly synthesized by the vascular endothelium where it seems to be bound to heparan sulphate or glycosaminoglycans (5). The binding mechanism is still not known. Tissue factor pathway inhibitor has been detected in human plasma mainly associated with lipoproteins (6) with a relative molecular mass of $M_{\mathrm{r}} 41000$. Bound tissue factor pathway inhibitor lacks the C-terminus including the third domain, only a small fraction consists of free tissue factor pathway inhibitor molecules with a relative molecular mass of $M_{\mathrm{r}} 34000$. Tissue factor pathway inhibi- 
tor functions as a potent natural anticoagulant (7) regulating tissue factor-mediated coagulation inhibition in the extrinsic pathway (8). Tissue factor pathway inhibitor directly inhibits factor $\mathrm{Xa}^{1}$ ) and, in a factor Xa-dependent reaction, factor $\left.\mathrm{VIIa}^{1}\right) /$ tissue factor catalytic complex. Heparin enhances the tissue factor pathway inhibitor inhibition of factor $\mathrm{Xa}$ and increases the plasma level of full-length tissue factor pathway inhibitor two to four-fold (9). Addition of heparin to blood samples does not change the tissue factor pathway inhibitor concentration. Therefore, the heparin-mediated increase seems to be part of intracellular or cell-membrane associated sources.

The von Willebrand factor, also known as the multimeric macromolecular carrier of factor VIII coagulant activity, is secreted by endothelial cells and platelets. It serves as a connecting bridge between platelets and injury-exposed vascular subendothelium (10-12). In laboratory diagnostics the von Willebrand factor serves as a marker of endothelial damage $(13,14)$. The cellular von Willebrand factor is either secreted directly from the cytosol or after stimulation, when von Willebrand factor is released by von Weibel-Palade bodies.

We investigated the effect of cyclosporine $A$ and/or polyethoxylated castor oil (cremophor EL) on the release of tissue factor pathway inhibitor from endothelial cells and used cell cultures to test this in vitro. Due to water insolubility, cyclosporine A is diluted in cremophor EL for intravenous injection and oral application with Sandimmune. We used cyclosporine A and cremophor EL at concentrations similar to in vivo levels during treatment of heart transplant patients.

\section{Materials and Methods}

\section{Blood collection}

In this study we included post heart transplant patients up to 6 years after transplantation immunosuppressed by cyclosporine $\mathrm{A}$ in therapeutical doses by oral administration. Blood samples were obtained from 50 blood donors and 50 heart transplant outpatients by drawing into citrated monovettes (9 vol blood to 1 vol $0.13 \mathrm{~mol} / \mathrm{l}$ trisodium citrate solution) or EDTA-prepared blood collection tubes. The blood collection of heart transplant patients was part of cyclosporine A monitoring every month. All samples were stored at $-70^{\circ} \mathrm{C}$ after centrifugation for $10 \mathrm{~min}$ at $2500 \mathrm{~g}$ until further use. After thawing, samples were centrifuged at $3000 \mathrm{~g}$ for $15 \mathrm{~min}$ to remove residual precipitates.

Measurement of tissue factor pathway inhibitor by a chromogenic substrate assay

The inhibitory activity of tissue factor pathway inhibitor was measured by a modified chromogenic substrate assay based on the ability to inhibit factor $\mathrm{X}$ activation by factor VIIa/tissue factor complex. Tissue factor $(25 \mu \mathrm{l})$ (dilution 1:80, Baxter, Unterschleißheim, Germany), $25 \mu$ l factor VII (0.0125 U, Sigma, Deisenhofen, Ger-

1) Enzymes (clotting factors):

Factor VII (EC 3.4.21.2)

Factor X (EC 3.4.21.6) many) were added to $25 \mu \mathrm{l} 0.075 \mathrm{~mol} / 1 \mathrm{CaCl}_{2}$ and $25 \mu 1$ factor $\mathrm{X}$ (0.025 U, Sigma, Deisenhofen, Germany) and incubated for $15 \mathrm{~min}$ at $37^{\circ} \mathrm{C}$ under vigorous shaking. Samples $(25 \mu \mathrm{l}$ ) (dilution up to $1: 20)$ were added and after the same incubation conditions additional $25 \mu$ l factor $X(0.4 U)$ were added, immediately. The chromogenic reaction was started after further incubation $(10 \mathrm{~min}$, $\left.37^{\circ} \mathrm{C}\right)$ by addition of $25 \mu$ l synthetic substrate $(2.7 \mathrm{mmol} / \mathrm{l}$ N-benzoyl-Ile-Glu-Gly-Arg-p-nitroanilide, Chromogenix, Essen, Germany). The absorbance was measured at $405 \mathrm{~nm}$ after $30 \mathrm{~min}$ substrate incubation. The clotting factors and samples were diluted in assay buffer containing $0.05 \mathrm{~mol} / 1 \mathrm{Tris} / \mathrm{HCl}, 0.1 \mathrm{~mol} / \mathrm{l} \mathrm{NaCl}$ and 10 $\mathrm{g} / \mathrm{l}$ human albumin (Armour Pharma, Eschwege, Germany), $\mathrm{pH}$ 8.0.

Our test system was calibrated with recombinant truncated two domain tissue factor pathway inhibitor (domain $\delta 1$ and $\delta 2$ ) (Novo Nordisk, Gentofte, Denmark) diluted in assay buffer. The inhibitory activity of tissue factor pathway inhibitor in the substrate assay was suppressed by addition of $100 \mathrm{ng}$ monospecific goat anti-tissue factor pathway inhibitor antibody (Novo Nordisk, Gentofte, Denmark) to the tested samples, thus indicating the specifity of the chromogenic test system.

\section{Quantification of von Willebrand factor antigen}

Von Willebrand factor antigen was measured in EDTA-plasma by a sandwich enzyme immunoassay (Boehringer Mannheim, Mannheim, Germany) and determined as percent of normal in plasma samples and $\mathrm{mU} / 1$ in cell culture supernatant.

\section{Quantification of cyclosporine A}

Cyclosporine A was determined in EDTA whole blood by an automated monoclonal antibody radio immunoassay not detecting cyclosporine metabolites (Ingstar/Sorin, Düsseldorf, Germany).

\section{Endothelial cell culture}

Human umbilical vein endothelial cells (Promocell, Heidelberg, Germany) were incubated in serum-free growth medium containing human epidermal growth factor $(10 \mathrm{mg} / \mathrm{l})$, bovine brain extract $(12 \mathrm{mg} / \mathrm{l})$, hydrocortisone $(1 \mathrm{mg} / \mathrm{l})$ and antibiotics $(50 \mathrm{mg} / \mathrm{l})$ (Promocell, Heidelberg, Germany). Human umbilical vein endothelial cells at the second passage after isolation were passaged in a solution of $0.5 \mathrm{~g} / 1$ trypsine and $0.2 \mathrm{~g} / 1$ EDTA (all Sigma, Deisenhofen, Germany) and seed in petri dishes of $60 \mathrm{~mm}$ diameter and grown to $80 \%$ confluence. The culture medium was refreshed before the cells were incubated with cyclosporine A (Sandimmun, Sandoz, Basle, Switzerland) in a concentration range from 20 to $200 \mathrm{mg} / \mathrm{l}$ and/or cremophor EL (Sigma, Deisenhofen, Germany) from 1 to $50 \mathrm{mg} / 1$.

Furthermore, endothelial cells were stimulated with calcium ionophore A $23187\left(10^{-4} \mathrm{~mol} / \mathrm{l}\right)$ (Sigma, Deisenhofen, Germany) alone or in combination with cremophor EL $(0-10 \mathrm{mg} / \mathrm{l})$. Constitutive tissue factor pathway inhibitor release in unstimulated cells was tested in cell culture medium as described above (Promocell, Heidelberg, Germany).

Over a period of four days, tissue factor pathway inhibitor containing supernatants were removed from whole plate per day for quantification. The cell number of every plate was counted microscopically.

Homogeneity, morphology and differentiation of the cultured cells were determined by microscopical inspection and during cell growth by flow cytometry using a monoclonal antibody directed against E-selectin (ELAM-1, Biozol, Eching, Germany) as a specific endothelial surface marker and HLA-ABC monoclonal antibody (Dianova, Hamburg, Germany) in a Becton-Dickinson FACScan analyzer with CELLQuest software. Lactate dehydrogenase catalytic concentration was determined to exclude limited cell death and was measured with a Syncron CX7 clinical chemistry analyzer (Beckman, CA). We measured the proliferative activity of the cell cultures under the influence of stimulating agents by a Cell-Prolif- 
eration-Kit (Boehringer Mannheim, Mannheim, Germany). All buffers and reagents were negative for pyrogenes or endotoxins.

\section{Statistical analysis}

All statistical analyses between patient groups were performed by the Kolmogoroff-Smirnov-test and the median test to evaluate statistically significant differences between collectives. The Komolgoroff-Smirnov-test is most stringent for not normally distributed independent samples.

Values of $p<0.001$ were considered to be statistically significant. For all groups and measurements we calculated the $90 \%$-range, mean value and standard deviation.

\section{Results}

Measurement of cyclosporine A in plasma of heart transplant outpatients

The cyclosporine A concentration in stable heart transplant outpatients was determined in a range from $130-280 \mu \mathrm{g} / \mathrm{l}$ representing the application of therapeutical doses by oral application. This concentration of cyclosporine A was chosen as the basis for cell culture experiments, as well as cremophor $\mathrm{EL}$ in an equivalent dose.

\section{Measurement of tissue factor pathway inhibitor in plasma samples}

Tissue factor pathway inhibitor was quantified in plasma samples of 50 blood donors ( 25 of each sex from 18-60 years). The standard deviation and mean value were $10.3 \mu \mathrm{g} / 1$ and $32.4 \mu \mathrm{g} / 1$, respectively. No significant sex or age dependencies were observed. Addition of $200 \mu \mathrm{g} / 1$ cyclosporine $A$ to the plasma samples showed no effect on the tissue factor pathway inhibitor determination in the chromogenic substrate assay.

In contrast, the determination of tissue factor pathway inhibitor in 50 stable heart transplant immunosuppressed patients showed a 2-4 fold increased tissue factor pathway inhibitor concentration. The standard deviation and mean concentration were $28.8 \mu \mathrm{g} / 1$ and $98.2 \mu \mathrm{g} / \mathrm{l}$, respectively (fig. 1). A correlation between cyclosporine $A$ and tissue factor pathway inhibitor concentrations was not observed. The tissue factor pathway inhibitor concentrations determined with our test system were significantly lower than expected. However, a clear difference between normal individuals and heart transplant patients was shown.

\section{Measurement of von Willebrand factor antigen in plasma samples}

In heart transplant outpatients we also found considerably enhanced levels of von Willebrand factor antigen. The standard deviation and mean value of von Willebrand factor antigen in heart transplant patients were $90.7 \%$ and $185 \%$, respectively. In blood donors the standard deviation was $29.9 \%$ and the mean value was $91 \%$ (fig. 2). No sex or age dependencies were observed. A correlation between von Willebrand factor antigen and cyclosporine A concentration was not observed.

\section{Endothelial cell culture}

Flow cytometric analysis showed constant homogeneity of the cells stained with ELAM-1 and HLA-ABC monoclonal antibody during four days incubation. Lactate dehydrogenase concentration was constant in all tested samples over the four days $(25-30 \mathrm{U} / \mathrm{l})$.

The proliferative activity of the cell culture was constant during the incubation with cremophor EL (fig. 3) for $14 \mathrm{~h}$. A dose-dependent effect was not observed. Incubation with the ionophore A $23187\left(10^{-4} \mathrm{~mol} / \mathrm{l}\right)$ alone or in combination with cremophor EL decreased the proliferative activity after $1 \mathrm{~h}$ (fig. 4 ).

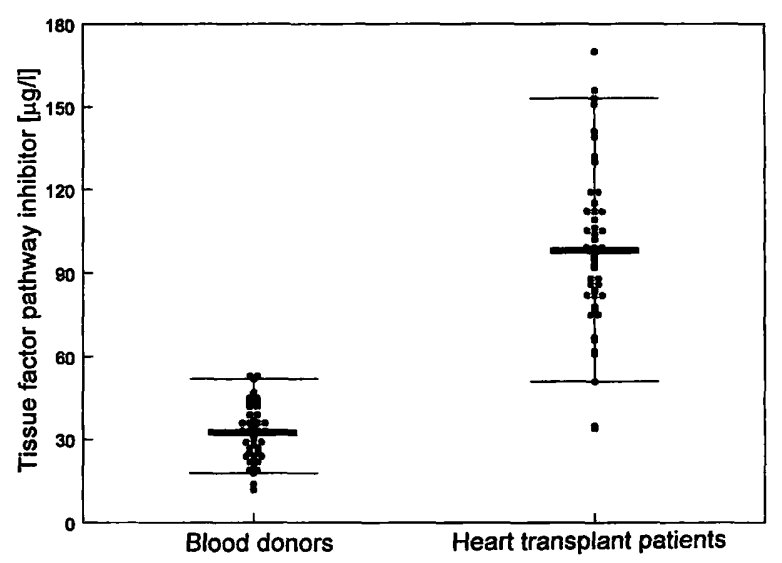

Fig. 1 Tissue factor pathway inhibitor concentration in citrated plasma of heart transplant patients $(n=50)$ compared to normal plasma from blood donors $(n=50)$ measured by a chromogenic substrate assay. The mean tissue factor pathway inhibitor concentration (bar) in organ transplant patients $(90 \mu \mathrm{g} / \mathrm{l})$ is approximately 3 -fold higher than in normal plasma $(30 \mu \mathrm{g} / 1)$. The $90 \%$-range in blood donors is $18-52 \mu \mathrm{g} / 1$ compared to $51-153 \mu \mathrm{g} / 1$ in immunosuppressed patients.

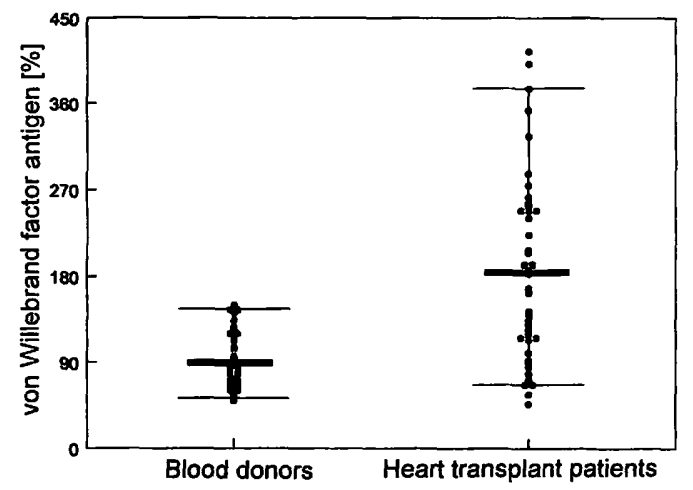

Fig. 2 Plasma concentration of von Willebrand factor antigen. The mean concentration and $90 \%$ range of von Willebrand factor antigen were $91 \%$ and $53-146 \%$ in blood donors $(n=50)$ in contrast to $185 \%$ and $67-376 \%$ in heart transplant patients $(n=50)$. 


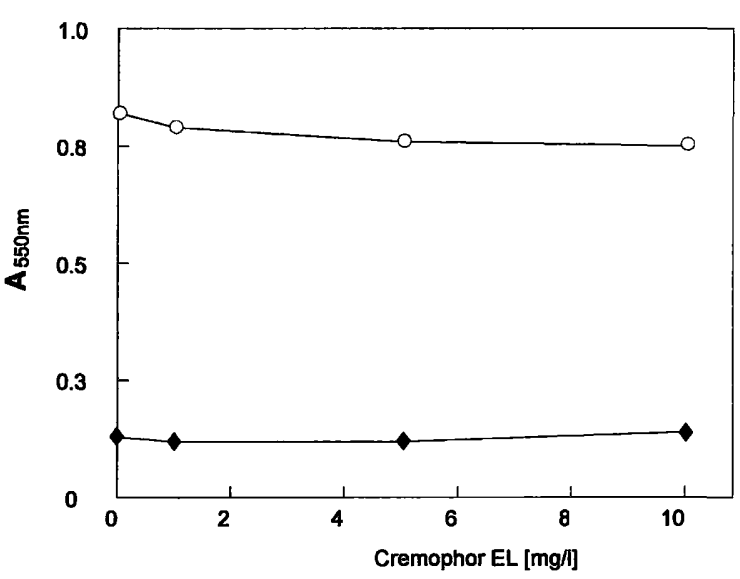

Fig. 3 Determination of endothelial cell proliferation $\left(10^{5}\right.$ cells per well) in response to different concentrations of cremophor EL with and without calcium ionophore A 23187. The absorbance $\left(\mathrm{A}_{550 \mathrm{~nm}}\right)$ represents the redox reaction of MTT to formazan salt by metabolic active cells.

O-O cremophor EL $(0-10 \mathrm{mg} / 1), \diamond-\diamond$ cremophor EL $(0-10$ $\mathrm{mg} / \mathrm{l})$ and ionophore A $23187\left(10^{-4} \mathrm{~mol} / \mathrm{l}\right)$.

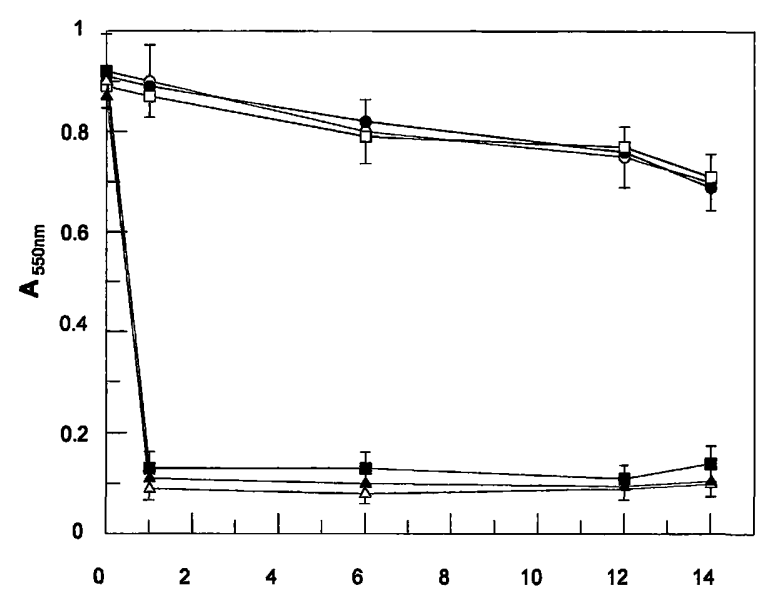

Fig. 4 Determination of endothelial cell proliferation $\left(10^{5}\right.$ per well). Cells were incubated with different concentrations of cremophor EL $(0-10 \mathrm{mg} / \mathrm{l})$ and ionophore A 23187 over a period of 14 hours. Endothelial cells $-\bullet$ without additives, $\bigcirc-\circ$ with $5 \mathrm{mg} / \mathrm{l}$ cremophor EL, $\square-\square 10 \mathrm{mg} / \mathrm{l}$ cremophor EL, $\mathbf{\square - \square} 10^{-4} \mathrm{~mol} / \mathrm{l}$ ionophore A 23187, $\Delta-\Delta 5 \mathrm{mg} / 1$ cremophor EL $+10^{-4} \mathrm{~mol} / 1$ A 23187 and $\triangle-\triangle 10 \mathrm{mg} / \mathrm{l}$ cremophor EL $+10^{-4} \mathrm{~mol} / 1$ ionophore A 23187.

\section{Measurement of tissue factor pathway inhibitor in endothelial cell culture medium}

To investigate the in vitro effect of cyclosporine A, endothelial cells were cultivated with different concentrations $(50-200 \mu \mathrm{g} / \mathrm{l})$ of cyclosporine A over a period of four days. Incubation with $20 \mu \mathrm{g} / 1$ and $50 \mu \mathrm{g} / 1$ cyclosporine A showed no significant tissue factor pathway inhibitor release in the cell culture supernatant (tissue factor pathway inhibitor, $69-195 \mathrm{ng} / 10^{5}$ cells and 91-183 $\mathrm{ng} / 10^{5}$ cells during the incubation period) in comparison to control medium without cyclosporine A (tissue factor pathway inhibitor, $66-183 \mathrm{ng} / 10^{5}$ cells during the incubation period). Addition of $100 \mu \mathrm{g} / 1$ to $200 \mu \mathrm{g} / \mathrm{l}$ cyclosporine A showed an increased release of tissue factor pathway inhibitor into the culture medium with $150-436 \mathrm{ng} / 10^{5}$ cells and $190-652 \mathrm{ng} / 10^{5}$ cells over a period of four days (fig. 5).

Cremophor EL $(50 \mu \mathrm{g} / \mathrm{l})$ alone did not alter the release of tissue factor pathway inhibitor compared to constitutive concentrations over a period of 24 hours. Increased tissue factor pathway inhibitor concentrations were observed after stimulation with the ionophore A 23187 $\left(120-160 \mathrm{ng} / 10^{5}\right.$ cells). When cremophor EL and A 23187 were added in combination, an elevated tissue factor pathway inhibitor concentration was detected (190-265 ng/10 cells) (fig. 6).

\section{Measurement of von Willebrand factor antigen in endothelial cell culture supernatant}

We also observed a significant correlation of von Willebrand factor antigen and cyclosporine $\mathrm{A}$ in cell culture medium dependent upon the cyclosporine concentration.

Von Willebrand factor antigen concentration did not alter significantly the first three days after cyclosporine A stimulation (3-9 $\mathrm{mU} / 10^{5}$ cells). A significant dose dependent effect of cyclosporine A was determined on day 4 . After addition of $50 \mu \mathrm{g} / 1$ and $100 \mu \mathrm{g} / \mathrm{l}$ cyclosporine A the von Willebrand factor antigen concentrations increased to $19 \mathrm{mU} / 10^{5}$ cells and $22 \mathrm{mU} / 10^{5}$ cells. Cells incubated with $20 \mu \mathrm{g} / 1$ cyclosporine A concentration or without cyclosporine A showed a lower von Willebrand factor antigen concentration in the cell culture supernatant with $10 \mathrm{mU} / 10^{5}$ cells and $6 \mathrm{mU} / 10^{5}$ cells (fig. 7 ).

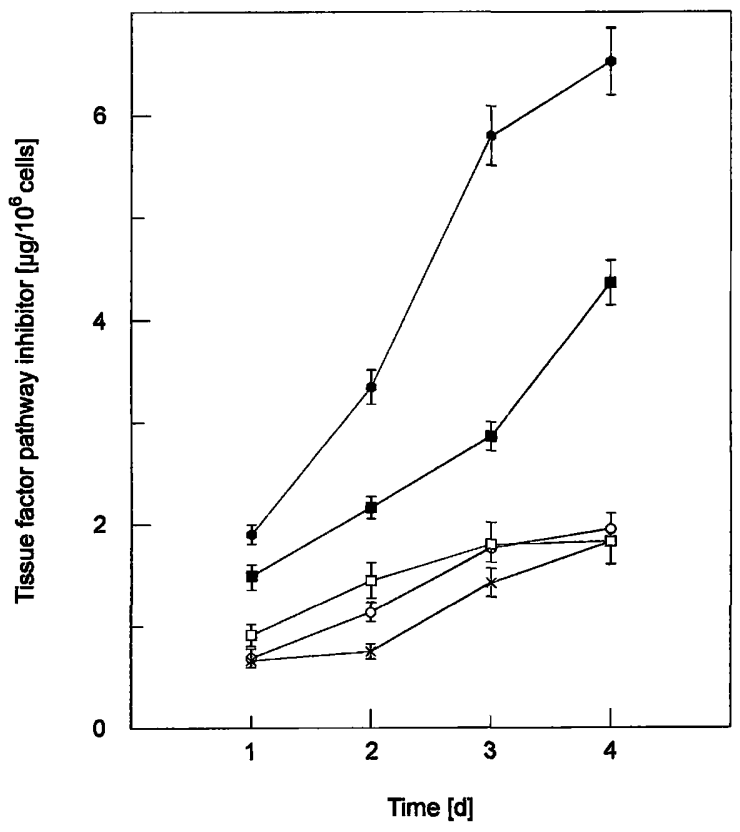

Fig. 5 Measurement of the released tissue factor pathway inhibitor in the cell culture supernatant of endothelial cells (ng/10 $/ 0^{5}$ cells) over a period of 4 days. Cells were incubated with different concentrations of cyclosporine A.

$\mathbf{x}-\mathbf{x}$ without cyclosporine $\mathrm{A}, \circ-\circ$ with $20 \mu \mathrm{g} / \mathrm{l}$ cyclosporine $\mathrm{A}$, $\square-\square 50 \mu \mathrm{g} / \mathrm{l}$ cyclosporine $\mathrm{A}, \mathbf{-}-\mathbf{1 0 0} \mu \mathrm{g} / \mathrm{l}$ cyclosporine $\mathrm{A}$ and - $200 \mu \mathrm{g} / \mathrm{l}$ cyclosporine A. 


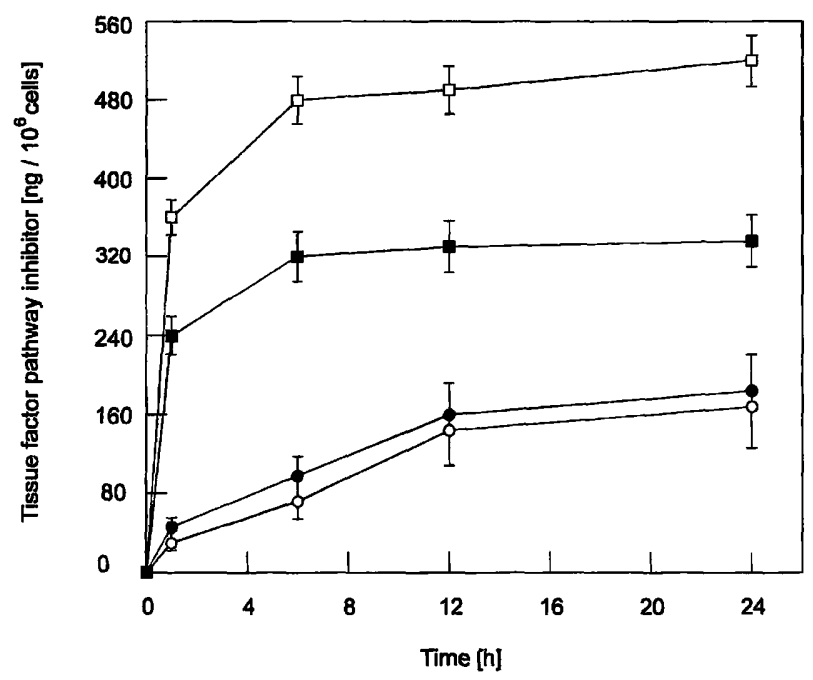

Fig. 6 Measurement of released tissue factor pathway inhibitor in the cell culture supernatant of endothelial cells $\left(10^{5}\right.$ per well) after incubation with cremophor EL and the calcium ionophore A 23187.

○-O cells without additives, - with cremophor EL $(10 \mathrm{mg} / \mathrm{l})$, - $10^{-4} \mathrm{~mol} / \mathrm{l}$ calcium ionophore A 23187, and $\square-\square$ cremophor EL $(10 \mathrm{mg} / \mathrm{l})+10^{-4} \mathrm{~mol} / \mathrm{l}$ calcium ionophore A 23187 .

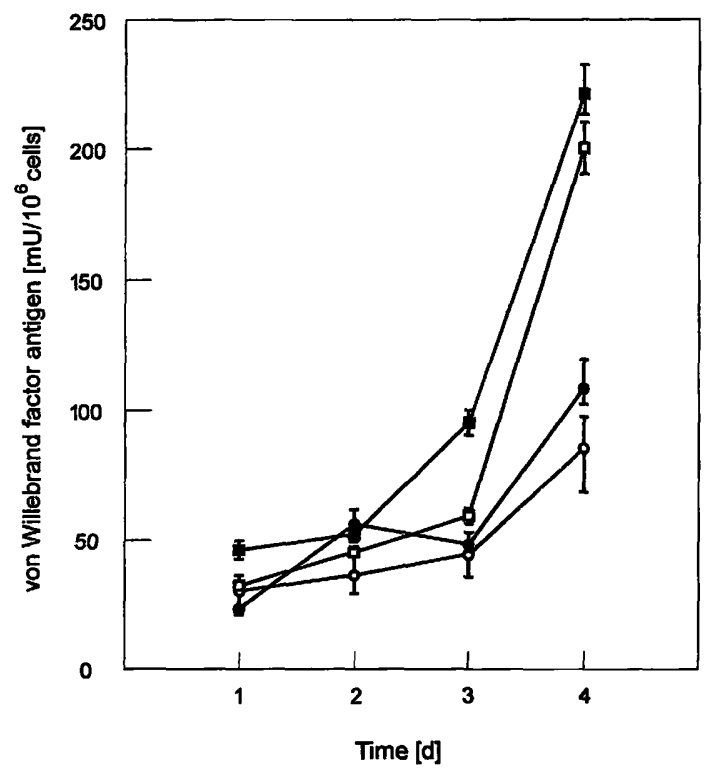

Fig. 7 Measurement of the von Willebrand factor antigen concentration in the culture supernatant of endothelial cells $\left(10^{5}\right.$ per well). The cells were incubated over a period of 4 days. Each value represents a separate petri dish.

$0-0$ cells cultivated without cyclosporine $A, \bullet-\bullet$ with $20 \mu \mathrm{g} / 1$ cyclosporine $\mathrm{A}, \square-\square$ with $50 \mu \mathrm{g} / \mathrm{l}$ cyclosporine $\mathrm{A}$ and $\square-\square$ with $100 \mu \mathrm{g} / \mathrm{l}$ cyclosporine A.

\section{Discussion}

Tissue factor pathway inhibitor is the main natural plasma inhibitor of the extrinsic pathway of coagulation $(15,16)$. Among other cell types tissue factor pathway inhibitor has been shown to be expressed by endothelial cells $(17,18)$, megakaryocytes, chondrocytes and synovial cells $(19,20)$. The extrinsic pathway is initiated by the tissue factor/factor VII complex, which is inhibited by tissue factor pathway inhibitor. Thus it is involved in prolonging factor Xa mediated coagulation time.

In the present study we have investigated the tissue factor pathway inhibitor concentration in immunosuppressed heart transplant patients. In comparison to blood donors, the tissue factor pathway inhibitor concentration in transplant patients was significantly higher. The mean tissue factor pathway inhibitor concentration of the blood donors was $32 \mu \mathrm{g} / \mathrm{l}$, wherease the mean tissue factor pathway inhibitor concentration of immunosuppressed patients was $98 \mu \mathrm{g} / \mathrm{l}$. Our chromogenic test system was calibrated with recombinant truncated tissue factor pathway inhibitor and was sufficient for the measurement of relative tissue factor pathway inhibitor concentration in transplant patients and normal individuals. However, the tissue factor pathway inhibitor concentrations determined with our chromogenic substrate assay were lower than published elsewhere $(21,22)$. In contrast to other chromogenic assays we used recombinant tissue factor pathway inhibitor for calibration. The specific inhibitory activity of recombinant tissue factor pathway inhibitor is higher than in normal pooled plasma resulting in lower tissue factor pathway inhibitor values in the chromogenic substrate assay.

In immunosuppressed patients a 2-4 fold increase of the inhibitory activity of tissue factor pathway inhibitor was observed. The mean therapeutic cyclosporine A concentration was $200 \mu \mathrm{g} / \mathrm{l}$. Cytotoxic effects of cyclosporine on endothelial cells are well known (1). Therefore, the increase of tissue factor pathway inhibitor in plasma of heart transplant patients let us suggest that cyclosporine A influences the tissue factor pathway inhibitor release from the endothelium into the extracellular space. Thus the concentration of released free tissue factor pathway inhibitor (not bound to lipoproteins) may reflect the damage of the endothelium which is considered to be the origin of plasma tissue factor pathway inhibitor. This is confirmed because addition of cyclosporine A to plasma samples showed no tissue factor pathway inhibitor elevation. If cyclosporine A upregulated the synthesis of tissue factor pathway inhibitor, we would expect an increase of total tissue factor pathway inhibitor in plasma. The chromogenic assay system used in this study could not answer this question, because the increased concentration of only functional active tissue factor pathway inhibitor was determined.

As von Willebrand factor is also a marker of endothelial cell damage processes $(23,24)$, we also measured plasma von Willebrand factor antigen in plasma of cardiac transplant patients. As with tissue factor pathway inhibitor, the von Willebrand factor antigen plasma levels were also increased in these individuals compared to healthy blood donors (tab. 1). 
Tab. 1 Tissue factor pathway inhibitor and von Willebrand factor antigen concentrations in blood donors $(n=50)$ and heart transplant outpatients $(n=50)$. The data include the mean value and $90 \%$ range.

\begin{tabular}{|c|c|c|c|c|}
\hline & $\begin{array}{l}\begin{array}{l}\text { Blood } \\
\text { donors }\end{array} \\
(\mathrm{n}=50) \\
{[\mu \mathrm{g} / 1]}\end{array}$ & $\begin{array}{l}\text { Heart } \\
\text { transplant } \\
\text { patients } \\
(\mathrm{n}=50) \\
{[\mu \mathrm{g} / 1]}\end{array}$ & $\begin{array}{l}\begin{array}{l}\text { Blood } \\
\text { donors }\end{array} \\
(n=50) \\
{[\%]}\end{array}$ & $\begin{array}{l}\text { Heart } \\
\text { transplant } \\
\text { pantients } \\
(n=50) \\
{[\%]}\end{array}$ \\
\hline Mean & 32.4 & 98.2 & 90.9 & 184.5 \\
\hline SD & 10.3 & 28.8 & 29.9 & 90.7 \\
\hline
\end{tabular}

From a pathophysiological point of view, the von Willebrand factor fosters platelet adhesion to damaged endothelium or exposed subendothelium. In persistently increased concentrations it may augment the cascade of events leading to transplant atherosclerosis. Newer investigations point to a role of von Willebrand factor as a coronary atherosclerosis risk (25).

Our investigations with endothelial cell cultures demonstrated a dose-dependent effect of cyclosporine $A$ on the cellular tissue factor pathway inhibitor and von Willebrand factor antigen release into the supernatant. Similar results were described with low molecular weight heparin on endothelial cells (26). Since no cell differentiation or cell damage was determined by flow cytometry, by microscopic inspection and by the measurement of lactate dehydrogenase catalytic activity concentration in the cell culture medium, we conclude that no cytotoxic effects occurred during incubation with cyclosporine $A$ in different concentrations. Therefore, we conclude that the release of tissue factor pathway inhibitor and von Willebrand factor antigen into the plasma of immunosuppressed patients is not a result of a severe vascular endothelial cell injury. The enhanced release can also be shown by coincubation with cremophor EL and nonphysiological agonist calcium ionophore A 23187. These results demonstrate that cremophor EL is the stimulating agent and cyclosporine A may function as cytosolic calcium modulator. Abraham and coworker
(27) previously described the effect of cremophor EL in a rat model. In these experiments a reduction in kidney interlobular arterial blood flow, decreased cardiac output and induced hypotension were observed, thus indicating that cremophor EL becomes active when administered orally or intravenously. Furthermore, cyclosporine A is described to increase the $\mathrm{Ca}^{2+}$ concentration in vascular smooth muscle cells (28), hepatocytes (29) and mesangial cells (30). Therefore, cyclosporine A seems to be responsible for the calcium influx to or release from intracellular stores.

Taken together, our results let us suggest that cyclosporine $A$ and its vehicle cremophor EL stimulate endothelial cells in the same way and induce tissue factor pathway inhibitor release into the extracellular space. These findings are in accordance with the enhanced von Willebrand factor antigen release, as described earlier $(1-3)$.

In contrast to von Willebrand factor, which has pro-haemostatic and atherogenic properties, tissue factor pathway inhibitor is a coagulation inhibitor and thus antithrombotic and probably anti-atherogenic.

The consequences of long term plasma elevation of tissue factor pathway inhibitor and von Willebrand factor antigen are difficult to calculate. Further studies on other endothelial-derived proteins in cyclosporine treated patients in connection with their coronary status are needed.

We recommend the measurement of endothelial derived proteins in clinical studies of new immunosuppressive agents (e. g. tacrolimus).

\section{Acknowledgements}

This work was supported by the Deutsche Forschungsgemeinschaft, Bonn-Bad Godesberg, SFB 223, within the project B08. We are indebted to Ms Anne-Kathrin Vollmer for her excellent technical assistance. We thank Dr. Ole Nordfang (Novo Nordisk) for providing recombinant truncated tissue factor pathway inhibitor and goat anti-tissue factor pathway inhibitor antibody. We are grateful to Ms Sarah L. Kirkby for her linguistic advice.

\section{References}

1. Zoja C, Furei L, Ghilardi F, Zilio P, Benigni A, Remuzzi G. Cyclosporine-induced endothelial cell injury. Lab Invest 1986; 55:455-2.

2. Bossaller C, Förstermann K, Hertel R, Olbricht C, Reschke V, Fleck E. Cyclosporine A inhibits endothelium-dependent vasodilation and vascular prostacycline production. Eur J Pharmacol 1989; 165:165-9.

3. Audi-Schwelk W, Bossaller C, Götze S, Thelen J, Fleck E. Endothelial and vascular smooth muscle function after chronic treatment with cyclosporine A.J Cardiovasc Pharmacol $1993 ; 21: 435-40$.

4. DeCaterina R, Tanaka H, Nakagawa T, Hauptmann PJ, Libby $P$. The direct effect of injectable cyclosporine and its vehicle, cremophor, on endothelial vascular cell adhesion molecule- 1 expression. Transplantation 1995; 60:270-5.

5. Hansen JB, Huseby NE, Sandset PM, Svensson B, Lyngmo V, Nordoy A. Tissue factor pathway inhibitor and lipopolysaccha-

rides - evidence for association with and regulation by LDL in human plasma. Arterioscler Thromb 1994; 14:223-9.

6. Hansen JB, Huseby KR, Huseby NE, Sandset PM, Hanssen TA, Nordoy A. Effect of cholesterol lowering on intravascular pools of TFPI and its anticoagulant potential in type II hyperlipoproteinemia. Arterioscler Thromb 1995; 15:879-85.

7. Novotny WF, Girard TF, Miletich JP, Broze GJ Jr. Platelets secrete a coagulation inhibitor functionally and antigenically similar to the lipoprotein-associated coagulation inhibitor. Blood 1988; 76:2020-25.

8. Hamamoto T, Yamamoto M, Nordfang O, Listke Petersen JG, Foster DC, Kisliel W. Inhibitory properties of full length and truncated recombinant tissue factor pathway inhibitor (TFPI). J Biol Chem 1993; 268:8704-12.

9. Sandset PM, Albigaard U, Larsen ml. Heparin induces release of extrinsic pathway inhibitor (EPI). Thromb Res 1988; 50:803-9. 
10. Legrand YJ, Rodrigues-Zeballos G, Kartalis G, Fauvel F, Caen JR. Adsorption of factor VIII antigen-activity complex by collagen. Thromb Res 1978; 13:909.

11. Baumgartner HR, Tschopp TB, Meyer D. Shear rate dependent inhibition of platelet adhesion and aggregation on collagenous surfaces by antibodies to human factor VIII von Willebrand factor. Br J Haematol 1980; 44:127.

12. Stel HV, Sakariassen KS, DeGroot PG, van Mourik JA, Sixma JJ. von Willebrand factor in the vessel wall mediates platelet adherence. Blood 1985; 65:85.

13. Boneu B, Abbal M, Plante J, Bierme R. Factor VII complex and endothelial damage. Lancet 1975; i:1430.

14. Corda R, Alberti M, Caocci L, Putzolu G, Mannucci PM. An increased factor VIII antigen as an indicator of endothelial damage in measles. Thromb Res 1979; 14:805.

15. Broze GJ. Tissue factor pathway inhibitor and the current concept of blood coagulation. Blood Coag Fibrinol 1995; 6:S7.

16. Broze GJ. Tissue factor pathway inhibitor. Thromb Haemost 1995; 74:90-3.

17. Bajaj MS, Kuppuswamy MN, Saito H, Spitzer SG, Bajaj SP. Cultured normal human hepatocytes do not synthesize lipoprotein-associated coagulation inhibitor: evidence that endothelium is the principle site of its synthesis. Proc Natl Acad Sci USA 1990; 87:8869-73.

18. Warn-Cramer BJ, Almus FE, Rapaport SI. Studies of the factor Xa-dependent inhibition of factor VIIa/tissue factor (extrinsic pathway inhibitor) from cell supernates of cultured human umbilical vein endothelial cells. Thromb Haemost 1989; 61:101-5.

19. Brinkmann T, Daum U, Tiemann C, Prohaska W, Kleesiek K. Improved chromogenic substrate assay of tissue factor pathway inhibitor (TFPI) using anti-TFPI antibodies and recombinant TFPI standard. Lab Med 1994; 9:384.

20. Brinkmann T, Kähnert H, Prohaska W, Nordfang O, Kleesiek K. Synthesis of tissue factor pathway inhibitor in human synovial cells and chondrocytes makes joints the predilected site of bleeding in haemophilacs. Eur J Clin Chem Clin Biochem 1994; 32:313-17.

21. Bognacki J, Hammelburger J. Functional and immunologic methods for the measurement of human tissue factor pathway inhibitor. Blood Coag Fibrinol 1995; 6:65-72.

22. Jeske W, Hoppenstedt D, Farred J, Bermes E. Measurement of functional and immunologic levels of tissue factor pathway inhibitor. Some methodologic considerations. Blood Coag Fibrinol 1995; 6:73-80.

23. Brinkhouse KM, Sultzer DL, Reddick RL, Griggs TR. Elevated plasma von Willebrand factor (VWF) levels as an index of acute endothelial injury:use of hypotonic injury models in rats. Fed Prod 1980; 39:630-42.

24. Holler E, Kolb HJ, Hiller E, Mraz W, Lehmacher W, Gleixner $B$, et al. Microangiopathy in patients on cyclosporine prophylaxis who developed acute graft-versus-host disease after HLA-identical bone marrow transplantation. Blood 1989; 73:2018-24.

25. Jansson JH, Nilsson TK, Johnson O. von Willebrand factor in plasma:a novel risk factor for recurrent myocardial infarction and death. Br Heart J 1991; 66:351-5.

26. Hoppenstaedt DA, Walenga JM, Fasanella A, Jeske W, Fareed J. TFPI antigen levels in normal human volunteers after intravenous and subcutaneous administration of unfractionated heparin and low molecular weight heparin. Thromb Res $1995 ; 77: 175-85$.

27. Abraham JS, Bentley RL, Garrison RN, Cryer HM. The influence of the cyclosporine vehicle, cremophor $\mathrm{EL}$, on renal microvascular blood flow in the rat. Transplantation 1991; 52:101-7.

28. Pfeilschifter J, Ruegg UT. Cyclosporine A augments angiotensin II stimulated rise in intracellular free calcium in vascular smooth muscle cells. J Biochem 1987; 248:883-90.

29. Nicchitta C, Kamoun M, Williamson J. Cyclosporine A augments receptor-mediated cellular $\mathrm{Ca}^{2+}$ fluxes in isolated hepatocytes. J Biol Chem 1985; 260:13613.

30. Pfeilschifter J. Cyclosporine A augments vasoconstrictor induced rise in intracellular free calcium in rat mesangial cells. Biochem Pharmacol 1988; 37:4205.

\section{Received April 7/ July 2, 1997}

Corresponding author: Dr. Thomas Brinkmann, Institut für Laboratoriums- und Transfusionsmedizin, Herz- und Diabeteszentrum Nordrhein-Westfalen, Universitätsklinik der Ruhr-Universität Bochum, Georgstraße 11, D-32545 Bad Oeynhausen, Germany Tel.: +49-5731-971390, Fax: +49-5731-972307, e-mail: HDZ.ILTM@post.uni-bielefeld.de 


.

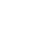

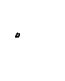

